\title{
Contested allegiances: Indian South Africans, passive resistance, and the 1947 royal visit to South Africa
}

\author{
Cacee Hoyer*
}

\begin{abstract}
This article examines the responses of the Indian South African community towards the 1947 British royal visit to South Africa. Following World War II, the African and Indian populations of South Africa were engaging in increasingly militant or "radical" political agendas. The Natal Indian Congress (NIC) encouraged a boycott of the royal visit as early as September 1946, citing its current participation in a passive resistance campaign targeting racist and discriminatory legislation recently passed against the Indian communities of South Africa. The NIC argued that while they respected the royal family, they could not celebrate their visit because it would be counter to the objectives of the campaign. However, despite the NIC's constant calls for boycott, the Indian community came out in mass to celebrate the royal family's visit to Durban in March 1947. As a result, this article places the royal visit at the centre of the discussion about the divisions within the Indian community; divisions which led to the failure of Indian resistance movements in the late 1940s and early 1950s. I argue that this moment exemplifies the various ways individual South African Indians prioritised particular layers of their identity that were determinant in their decision to support or defy the political objectives of their leadership at the height of a mass resistance campaign.
\end{abstract}

Key Words: A.I. Kajee; British Empire; Ghetto Act; Natal Indian Congress; Natal Indian Organisation; passive resistance; royal visit

\section{Opsomming}

Hierdie artikel gaan die reaksies na van die Suid-Afrikaanse Indiese gemeenskap op die Britse koningsgesin se besoek aan Suid-Afrika in 1947. Ná afloop van die Tweede Wêreldoorlog het die Afrika- en Indiese bevolkings van Suid-Afrika toenemend betrokke begin raak by militante of "radikale" politieke agendas. Die Natal Indian Congress (NIC) het so vroeg as September 1946 'n boikot van die koninklike besoek aangemoedig, op grond van hul destydse deelname aan 'n passiewe

* Cacee Hoyer is an assistant professor in History at the University of Southern Indiana. She has co-edited two volumes with Toyin Falola, namely, Global Africans: Race, Ethnicity, and Shifting Identities (Routledge, London, 2017); and Human Rights, Race, and Resistance in Africa and the African Diaspora (Routledge, London, 2016). I am indebted to Prof Anthony Edwards and Prof Jason Morgan for their essential contributions to this project.

How to cite this article: C. Hoyer, "Contested allegiances: Indian South Africans, passive resistance, and the 1947 royal visit to South Africa", Historia, 64, 1, May 2019, pp 91-110. 
weerstandsveldtog gemik op die rassistiese en diskrimenerende wetgewing wat kort vantevore teen die Indiese gemeenskappe van Suid-Afrika aangeneem is. Die NIC het betoog dat, alhoewel hulle die koningsgesin eerbiedig, hulle nie hul besoek kon vier nie aangesien dit in teenstelling met die doel van hul veldtog sou wees. Desnieteenstaande, ten spyte van die NIC se voortdurende oproepe tot 'n boikot, het die Indiese gemeenskap in groot getalle opgeruk om die koningsgesin se besoek aan Durban in Maart 1947 te vier. Gevolglik plaas hierdie artikel die koninklike besoek in die middel van 'n bespreking oor die verdelings binne die Indiese gemeenskap wat gelei het tot die mislukking van Indiese weerstandbewegings in die laat 1940's en vroeë 1950's. Ek betoog dat hierdie oomblik as voorbeeld dien van die onderskeie maniere waarop individuele Suid-Afrikaanse Indiërs sekere lae van hul identiteit geprioritiseer het, wat bepalend was in hul besluit om die politieke doelwitte van hul leierskap gedurende die hoogtepunt van 'n massaweerstandsveldtog te ondersteun of uit te daag.

Sleutelwoorde: A.I. Kajee; Britse Ryk; Ghetto Act; Natal Indian Congress; Natalse Indiese Vereniging; passiewe weerstand; koninklike besoek.

Your South African Indian people of this city of Durban the largest colony of Indians in the Southern Hemisphere outside India-extend, with our homage and loyalty, a warm and cordial welcome to Your Majesties. Our hearts are filled with joy to be in your midst. ${ }^{1}$

On June 3, 1946, the South African government passed the Asiatic Land Tenure and Indian Representation Act (No. 28 of 1946) better known as the "Ghetto Act", which restricted Indian ownership and occupation of land in newly determined so-called "European" areas and granted token representation through elected white councillors. The Indian community of Natal maintained a passive resistance campaign from June 1946 until June 1948 to protest this discriminatory legislation. In the midst of these protests, the British royal family, which included King George VI, the queen, and the two royal princesses, conducted a two-month official visit to South Africa. This article contends that the confluence of these two events revealed a deep divide within the Indian South African community, as well as indicating a divergence in Indian identity in South Africa, at a time when calls for unity were of the utmost political priority.

Indians first arrived in South Africa in 1860 as a result of the British imperial indenture system. Most of the Indian people decided to stay in South Africa, primarily in Natal, after their five years of indenture. By the 1880s a second "wave" of Indians arrived in South Africa, most of whom were wealthy merchants and are often referred to as "passenger" Indians because they were able to pay their own way to South Africa. By the time of this second wave of Indian immigration, many white South Africans began to complain about Indian "encroachment" and the first discriminatory

1. A.I. Kajee, chairman of the Reception Committee, in his welcome speech to the royal family. "Indians Welcome Their Majesties," The Leader, 27 March 1947. 
legislation against Indians was passed. Mohandas Gandhi became famous for developing his non-violent resistance strategies, known as satyagraha, against such legislation in the early years of the 20 th century. $^{2}$

By the post-World War II period, discriminatory legislation targeting Indians and the protests which followed were not new to Natal. ${ }^{3}$ The Indian South African leadership, represented by the Natal Indian Congress (NIC), protested the 1946 socalled "Ghetto Act" by launching a mass non-violent protest, based on Gandhi's ideals of satyagraha. The protesters camped out on prohibited land, courted arrest, and celebrated their experiences in jail with the ultimate goal of making the plight of the Indian people known on the world stage, notably at the first meeting of the United Nations in San Francisco. Simultaneously, the government of India took the issue (subsequently called the Indian Question) to the United Nations, where it was decided in December 1946 that the governments of South Africa and India should hold a

2. The first discriminatory laws targeting Indians (Law 3 of 1885) limited ownership of property and residences to designated areas and denied citizenship rights. Mohandas Gandhi's first passive resistance campaign targeted the Asiatic Registration Bill of 1906 which required Indian males to register and have their fingerprints recorded, limited trade and segregated living areas for Indians in the Transvaal. Subsequently Gandhi's passive resistance activities included burning of registration documents; trading without licenses; crossing provincial borders without permits; protesting the burdensome $£ 3$ tax on ex-indentured Indians, and the recognition of Hindu and Muslim marriages. For more information on Gandhi's satyagraha in South Africa, see A. Desai and G. Vahed, The South African Gandhi: Stretcher-Bearer of Empire (Stanford University Press, California, 2016); D. Arnold, Gandhi (Longman, New York, 2001); S. Bhana, Gandhi's Legacy: The Natal Indian Congress, 1894-1994 (University of Natal Press, Pietermaritzburg, 1997); J. Brown, Gandhi: Prisoner of Hope (Yale University Press, New Haven, 1998); A. Desai and G. Vahed. Inside Indian Indenture: A South African Story, 1860-1914 (HSRC Press, Cape Town, 2010); I. Hofmeyr, Gandhi's Printing Press: Experiments in Slow Reading (Harvard University Press, Cambridge, 2013); R. Huttenback, Gandhi in South Africa: British Imperialism and the Indian Question, 1860-1914 (Cornell University Press, Ithaca, 1971); J. Lelyveld, Great Soul: Mahatma Gandhi and his Struggle with India (Alfred Knopf/Random House, New York, 2011); M. Swan, Gandhi: The South African Experience (Ravan Press, Johannesburg, 1985); K. Hiralal, "Indian Family Businesses in Natal, 1870-1950", Natalia, 38(2008), pp 27-37; B. Guest, “Gandhi's Natal: The State of the Colony in 1893”, Natalia, 23 (1993), pp 68-75.

3. During the 1920 s and 1930 s a sundry list of discriminatory laws was passed to limit or control Indians (and Africans), including liquor acts, franchise bills, riotous assembly acts, denial of right to become naturalised citizens, land tenure acts, dealers licensing ordinances, and mixed marriages, to name a few. By 1943 the "Pegging Act" (The Asiatic Trading and Occupation of Land Act) restricted trading and occupation/acquisition of land in the Transvaal and Natal. The Pegging Act expired on 31 March 1946, which prompted the Asiatic Land Tenure and Representation Act, or "Ghetto Act", of 1946. This prompted resistance by means of the passive resistance campaign discussed in this article. 
roundtable discussion to resolve the issue of discrimination against Indian people living in South Africa. ${ }^{4}$

The NIC initially heralded this verdict as a resounding success. However, they were unable to persuade the South African government to comply and failed to garner further support in the 1947 United Nations sessions to sustain this pressure. As a result of failing to overturn the Ghetto Act, largely due to internal division among the Indian community, the government's divisive tactics, and violent police action, the Indian South African leadership struggled to consolidate a mass satyagraha movement, which could garner the international sympathies needed at subsequent UN meetings. Nothing exemplified the divisions within the movement in Natal more than the royal visit of 1947.

At the same time that the South African legislature was putting the Ghetto Act through parliament, South Africans were also preparing for the British royal visit. ${ }^{5}$ The South African prime minister at the time, Jan Smuts had invited the British royal family to tour South Africa in early 1947, primarily to use the allure of the crown to garner support for his weakening United Party. ${ }^{6}$ Smuts told the Natal Daily News that the royal visit would "serve a very great purpose in counteracting the propaganda

4. For further reading, see J. Soske, Internal Frontiers: African Nationalism and the Indian Diaspora (Ohio University Press, Athens, 2017); G. Vahed and A. Desai, “Monty... Meets Gandhi ... Meets Mandela: The Dilemma of Non-violent Resisters in South Africa, 1940-60", in I. Hofmeyr and M. Williams (eds), South Africa and India: Shaping the Global South (Wits University Press, Johannesburg, 2011), pp 105-125; U. Dhupelia-Mestrie and S. Bhana, "Passive Resistance among Indian South Africans: A Historiographical Survey", South African Historical Journal, 16(1984), pp 118-31; J. Shearar, Against the World: South Africa and Human Rights at the United Nations 1945-1961 (Unisa Press, Pretoria, 2011); S. Dubow, "Smuts, the United Nations, and the Rhetoric of Race and Rights", Journal of Contemporary History, 43 (2008), pp 4574; B.L. Viranna, "Black Political Resistance in Natal, 1947-1952", Master's dissertation, University of Durban-Westville, 1994; U. Dhupelia-Mestrie, "Indian Responses in Natal to Non-European Unity Moves, 1927 to 1945", Journal of Natal and Zulu History 12 (1989), pp 73-89; B. Pachai, The International Aspects of the South African Indian Question, 1860-1971 (C. Struik, Cape Town, 1971); E.S. Reddy, Struggle for Freedom in Southern Africa: Its International Significance (Mainstream, New Delhi, 1987).

5. The tour lasted three months (February to April) and visited every major urban area in South Africa. It also explored rural areas, such as the Karoo, the Cecil Rhodes memorial site, and Victoria Falls. It also included parts of Southern Rhodesia (now Zimbabwe), Swaziland, Basutoland (now Lesotho), and Bechuanaland (now Botswana). For the most part they travelled by train, covering more than 10000 miles.

6. H. Sapire and A. Grundlingh, "Rebuffing Royals? Afrikaners and the Royal Visit to South Africa in 1947", The Journal of Imperial and Commonwealth History, 46(2018), pp 524-551; J. Lambert, “Welcome Home': White English-speaking South Africans and the Royal Visit of 1947", South African Historical Journal, 69(2017), pp 101-120; M. Dibben, "The Royal Tour of 1947", Honours essay, University of Natal-Durban, 1985. 
against South Africa overseas". Here he referred to negative representations of South Africa at the United Nations regarding the treatment of Indian people and the controversial claim Smuts was making for permission to incorporate South West Africa (now Namibia) into South Africa as a fifth province. Claiming that the king would see first-hand "that Britain has nothing to be ashamed of and much that His Majesty and the British nation may feel justly proud of", ${ }^{7}$ Smuts hoped to squelch growing discontent with United Party policies. However, the royal visit was coming in the midst of post-war political turmoil in the country at large and among the various populations of South Africa. The African leadership was engaged in increasingly militant political agendas and asserting African nationalism. Simultaneously, in 1945, a younger, more "radical" Indian South African leadership, led by two medical doctors, Yusuf Dadoo and Monty Naicker, replaced the more moderate pre-war leadership of A. I. Kajee and P.R. Pather. By 1946, these younger radical leaders commenced the passive resistance campaign that lasted until mid-1948.

The British, and Smuts, saw the growing support in South Africa of Afrikaner nationalism as a threat to South Africa's position in the Commonwealth, which was especially important with Indian independence looming and the weakening of colonial control in Asia and Africa. Historically, royal tours were the epitome of performance politics. They were designed to provide access to the royal family by their imperial subjects; they allowed the monarchy the opportunity to "parade" icons of the British Empire while eliciting evidence of loyalty from their subjects. ${ }^{8}$ According to the World Review, a British illustrated weekly magazine, "there is the hope that continuing loyalty from South Africa will be impressive to India and Burma. King George [VI] may strengthen the Government's hand in maintaining order". ${ }^{9}$ The 1947 visit was the first time a reigning member of the royal family had visited South Africa. ${ }^{10}$

7. Natal Daily News, 13 February 1947.

8. Sapire and Grundlingh, "Rebuffing Royals?" pp 525-526; Lambert, "Welcome Home”, pp 103-104; H. Sapire, "African Loyalism and its Discontents: The Royal Tour of South Africa, 1947", The South African Historical Journal, 54 (2011), p 222.

9. World Review, 11 February 1947. The World Review was an illustrated weekly magazine belonging to the Hulton Group of publications; it also published illustrated periodicals such as Picture Post and Lilliput.

10. Royal tours were common throughout the Commonwealth, but this was the first by a King or Queen to South Africa prior to 1947. The two previous royal visits were by the Duke (Prince Arthur) and Duchess of Connaught in 1910 and then, in 1925, by the Prince of Wales (later King Edward VIII, who subsequently abdicated). For more information, see H. Sapire, "Ambiguities of Loyalism: The Prince of Wales in India and Africa, 1921-2 and 1925", History Workshop Journal, 73(2012), pp 37-65; A. Thompson, "The Languages of Loyalism in Southern Africa, c. 1870-1939", The English Historical Review, 477(2003), pp 617-650; T. Aronson, Royal Ambassadors: British Royalties in Southern Africa, 1860-1947 (David Philip, Cape Town, 1975). 


\section{The Indians protest against the royal visit}

On 22 March 1947, the British royal family arrived in Durban, where 65000 Indians gathered at Curries Fountain to celebrate the occasion, despite the NIC's call for a mass boycott of the royal visit. ${ }^{11}$ Why did almost half of Durban's Indian population contravene its leadership's directives? How did what many people believed to be a "comparatively unimportant event" transform into a "divisive force in the Indian community", at a time when it required utmost cohesion? ${ }^{12}$ And how did this local disagreement impact the larger political issue of the Indian Question at the United Nations? In this article, I examine the responses of the Indian community towards the NIC and the royal visitors, arguing that this event contributed to the breakdown of relationships between the Indian people and their leadership, which had significant ramifications for the maintenance of morale and garnering support for the passive resistance campaign. I also question the various ways in which individual Indians prioritised particular layers in their identity in determining whether to join the celebration of the royal visit or boycott it.

As early as September 1946, the NIC encouraged a boycott of the royal visit, claiming, "while the Indian community finds itself in such an unhappy situation in part of His Majesty's Empire, it is most unreasonable to expect Indians to participate in any rejoicing or celebrations in honour of Royalty". ${ }^{13}$ While finding the boycott a "matter of profound grief", the NIC extolled their constituents to treat the royal visit as a "day of mourning and all should be confined to their homes". ${ }^{14}$ The NIC executive understood the hypocrisy of these two ideals: honouring British royalty while suffering racial prejudice within a Commonwealth country. The NIC leadership recognised the goal of the South African government in creating propaganda for international audiences, especially in light of the previous year's UN decision. So, the NIC encouraged the Indian community, despite it being a "bitter pill to swallow", to not provide the smiling and happy crowds required to create the illusion of racial harmony in the South Africa. ${ }^{15}$

11. "Natal Indians Welcome Royal Family", Indian Views, 26 March 1947.

12. F.M. Barr, "A European View of the Boycott of the Royal Visit," Indian Opinion, 14 March 1947. Barr was a self-proclaimed supporter of the passive resistance movement and habitual reader of the Indian Opinion, claiming that he did not represent any "organised body of European opinion" but wanted to share his thoughts on the Indian boycott of the royal visit, which, for the most part, he supported.

13. Durban Regional Archive (hereafter DBN): 3/DBN 4/1/3/1971, Folder 3, A.I. Meer, Joint Honorary Secretary of the Natal Indian Congress to A.N. Barker, Mayoral Secretary, "Re: Royal Visit”, 11 September 1946. The original letter was reprinted in all three Natal Indian papers (The Leader; Indian Views; and Indian Opinion) as well as the Natal Mercury, the Guardian and many other South African and international newspapers.

14. "Welcome to the Royal Family", Indian Opinion, 14 February 1947; and "Indians and the Royal Visit", Indian Opinion, 31 January 1947.

15. "Welcome to the Royal Family", Indian Opinion, 14 February 1947. In an attempt to illustrate its support and perhaps to respond to its opponents, the NIC publicised the fact that over 100 delegates to the NIC from all parts of Natal had agreed to the 
This protest was not without its risks. In response to receiving the NIC's letter about the boycott, the mayoral secretary forwarded copies to the municipal police department and the colonial administrator, Mr Mitchell. ${ }^{16}$ Despite a response from the administrator that "officially the matter should be permitted to rest at the present stage", later the following week the police were reported to have raided the homes of multiple prominent NIC organisers. ${ }^{17}$ With no clear purpose, the police were reported to have taken documents "indiscriminately", such as an English dictionary from M.P. Naicker, secretary of the Passive Resistance Council. ${ }^{18}$ Such retaliatory actions taken by the government, although not surprising, bolstered the leadership's sense of justification in calling for a boycott, and compound an already contentious situation.

It is important to note that this moment also reveals that the Indian South African leadership no longer identified along imperial lines, instead expressing new "extremist" views of South African and Indian nationalisms. For example, prior to World War II, any grievance by Indian South Africans that was aired internationally, was done through British imperial channels. For example, Mohandas Gandhi, the most well-known activist for Indian South Africans prior to World War II, petitioned Britain on behalf of the Indians in South Africa. By March 1947, however, the socalled "radical" Indian South African leadership was engaged in a movement for unity with the African leadership for the first time. Using nationalist language, they claimed an urgency for inter-racial co-operation to fight for the "basic human rights and full citizenship" for all South African peoples. ${ }^{19}$ As a result, the Indian South African leadership believed its constituency needed to identify as "South African" first and foremost rather than "Indian" or "British". The Indian South African leadership understood that the British, as an imperial power, were at odds with the new nationalist sentiments swelling throughout Africa and India, causing the leadership to reprioritise their identities while much of the general population simply did not follow suit.

Initially, the NIC notified the Regional Committee that was organising Natal's celebrations for the royal visit that it would not send representatives to the NonEuropean Subcommittee in September 1946. The Regional Committee responded by saying it was:

boycott. Supporters included 12 branches, 10 Passive Resistance Action Committees, and a number of trade union organisations. See "Royal Visit", Indian Views, 26 February 1947.

16. DBN: 3/DBN 4/1/3/1971, Folder 3, A.N. Barker, Mayoral Secretary to Hosking, MEC, "Re: Royal Tour, Natal Indian Congress".

17. "Police Raid Congress Offices," The Leader, 28 September 1946.

18. "Police Raid Congress Offices," The Leader, 28 September 1946.

19. University of KwaZulu Natal, Gandhi-Luthuli Documentation Centre (hereafter GLDC), "Joint Declaration of Cooperation", signed by A.B. Xuma (President of the ANC), G.M. Naicker (President of the NIC) and Y.M. Dadoo (President of the TIC), on 9 March 1947. 
... most anxious that every section of the Indian community should be given the opportunity of participating in Durban's welcome to our Royal visitors, and consequently the Committee is proceeding with its original plans to provide some convenient opportunity for this purpose. ${ }^{20}$

No further communication occurred until December, when the Regional Committee contacted A.I. Kajee, a so-called "moderate" Indian leader to organise the event.

A.I. Kajee had recently (October 1945) been ousted from leadership of the NIC by the more radical G.M. Naicker. Historically, Kajee had sought amicable relations with the white residents, meeting occasionally with Prime Minister Smuts. Kajee's party platform professed the necessity of "good relations with Europeans", which "must at times leave unsaid what [the Indians] might wish to say and at other times leave undone things they wished to do".21 The ousting of Kajee in late 1945 was primarily based on criticism of this approach towards the 1943 "Pegging Act", which acted as a precursor of the 1946 Ghetto Act. The replacement of Naicker and Dadoo as leaders of the NIC and TIC respectively, are generally accepted as an indication that the Indian masses preferred the radical nationalisms of the "new guard" over Kajee's traditional collaborative stance. Therefore, when Kajee was able once again to cull the masses as a result of the royal visit, he (and the white government) assumed he had regained the favour of the Indian South African people.

The boycott was proclaimed throughout the Indian and white press of South Africa and abroad when the NIC found out about Kajee's plan. However, despite the NIC boycott, Kajee and his committee organised a celebration at Curries Fountain sports complex for the royal family. ${ }^{22}$ Kajee, along with P.R. Pather, also a prominent moderate Indian leader, created the opposition party of the Natal Indian Organisation (NIO) a few months following the visit. Those Indians loyal to the NIC considered Kajee, Pather, and their supporters as collaborators with the Smuts government for many of their actions that opposed NIC directives, such as encouraging active participation in the royal visit. ${ }^{23}$

20. DBN: 3/DBN 4/1/3/1971, Folder 3, A.N. Barker, Mayoral Secretary to A.I. Meer, Joint Honorary Secretary of the NIC, "Re: Royal Visit", 16 September 1946.

21. G.H. Calpin, A.I. Kajee: His Work for the South-African Indian Community (Iqbal Study Group, Durban, c. 1950), p 149.

22. For further reading, see V. Goolam and T.Waetjen, "Shifting Grounds: A.I. Kajee and the Political Quandary of 'Moderates' in the Search for an Islamic School Site in Durban, 1943-1948”, South African Historical Journal, 67(2015), pp 316-334; Bhana, Gandhi's Legacy; Calpin, A. I. Kajee: His Work for the South African Indian Community.

23. “Congress Going Communist?", Inkundla Ya Bantu, 10 April 1947; "Natal Indians Divided”, Inkundla Ya Bantu, 8 May 1947; “Congress Cry 'Cowards!”, Leader, 3 January 1948; "Speakers Called “Traitors'”, Leader, 3 January 1948; “TIO Formed”, Leader, 3 January 1948; "Indian Political Movements in South Africa", South African Police Report for the Secretary of External Affairs, 30 January 1948; and Killie Campbell Africana Library, Durban, Nicholls Papers, File 39. 
It was not inconsequential that Kajee and Pather initiated the NIO shortly after the visit. ${ }^{24}$ Legitimately they felt they had the ear of the people, arguing that the turnout at the royal visit was essentially a mandate of the people for new leadership. As a result, the royal visit acted as the catalyst for the creation of competing political bodies, both claiming to represent the Indian community of South Africa, serving to discredit both organisations at the meeting of the United Nations general assembly later that year. ${ }^{25}$

The result of Kajee's efforts included a giant reproduction of the Taj Mahal, a parade by 20000 boy scouts and schoolchildren, and festivities that lasted into the evening despite the early departure of the royal family. ${ }^{26}$ The Taj Mahal itself was an obvious marker of Indian South African identity at the time, but they also reportedly paraded the schoolchildren into Curries Fountain to form the outline of the [British] Indian Empire. ${ }^{27}$ The Durban Indian Planning Committee even requested to garland the King and Queen according to the "traditional form of Honour following precedent at New Delhi set by late King George [V]", which request was incidentally denied by the Natal Administration. ${ }^{28}$ Had they identified primarily as South African, as their leadership did, then such reproductions and performances of Indian (rather than Indian South African) heritage would have been unimaginable. Additionally, celebrations of British Empire were also strangely out of line with Indian identity at the time, considering that India had gained its independence from the British Empire just months following this visit.

The Natal Indian newspaper, The Leader, proclaimed the gathering the "largest ever public gathering of South African Indians", and the local African press described the scene: a "majority of stores in Grey Street [Indian commercial district] displayed flags and bunting in honour of the king", with a giant streamer across from the NIC's Grey Street office which read: "The Indian Community Welcomes the Royal Family."29 Their offices not being directly on the parade route, it can be concluded that such a message was directed towards the NIC itself and not necessarily the royal visitors.

The NIC encouraged a boycott of the royal visit so that such an exhibition would not misrepresent the plight of the average Indian South African to the royal family. However, since the boycott was disregarded, and no diplomatic opportunity was allowed to the Indian political leadership, aside from A.I. Kajee and other "moderates" who enjoyed an audience with the royal family, the royal visit was applauded as a success by many South African government officials. In fact, Prime

21. The NIO was formalised at a conference held in Durban on 4 May 1947, just six weeks after Kajee met King George VI.

25. “The Next Step", Indian Opinion, 28 November 1947; and Shearar, Against the World.

26. “Natal Indians Welcome Royal Family”, Indian Views, 26 March 1947.

27. "Taj Mahal Canopy for Royalty”, The Leader, 1 March 1947.

28. Pietermaritzburg Regional Archive (hereafter PMB): 3/PMB 4/4/2/205, telegram, Royal Visit Organising Committee to Pietermaritzburg Town Clerk, 5 March 1947.

29. “The Royal Visitors”, Leader, 22 March 1947; Inkundla Ya Bantu, 8 May 1947; Inkundla Ya Bantu, 27 March 1947. 
Minister Smuts, who accompanied the royal family, was reported as being "obviously very pleased at the spontaneous welcome accorded to the royal visitors". ${ }^{30}$

Perhaps most significantly, the Durban visit lasted less than 35 minutes. 31 The extensive time and money spent on preparations for such a brief interaction are notable. However, the airing of the disparity between the Indian masses and the leadership was perhaps the most damaging and costly 35 minutes within the entire passive resistance campaign.

\section{Personal accounts}

The Natal Indian Congress (NIC), despite acknowledging the general "great attraction that such an occasion [the royal visit] would naturally cause", showed how deeply they were disconnected from the Indian people, many of whom were eager to join the celebrations to welcome the royal family. ${ }^{32}$ The leadership did not recognise the celebrity power of British royalty. Arjun Pillai, recalled the media frenzy, noting that "the English newspapers were agog, the Royal family going here, going there, photograph[ing] all the places they visited". ${ }^{33}$ Ram Jagkaran, a 17-year-old bus clerk at the time, remembered illegally cutting through the fence by the bus rank to get a glimpse of the royal family as their train passed the station. He said in an interview:

... as they were passing by they were waving and like ... you can't even go and see the King and Queen, you're not allowed to go. We just knew they were leaving at a certain time, so we were there, and we waited at the rail line to see the train. ${ }^{34}$

Both Pillai and Jagkaran show us that many working and middle-class Indians did not approach the royal visit on an ideological plane. They were drawn to the energy of the festivities, the break from routine day-to-day activities, and the chance of possibly glimpsing the famous family. Indeed, scores of pamphlets were printed to celebrate and memorialise the visit. In most cases funded by the government, these pamphlets claimed "the public wants to keep those memories and that loyalty alive and has clamoured for some permanent souvenir of the Royal Family's stay in the Union"35

30. “Natal Indians Welcome Royal Family”, Indian Views, 26 March 1947.

31. PMB: 3/PMB 4/4/2/205, Agenda for the Royal Visit, Durban, 18 March 1947.

32. "Mr. Heaton Nicholls", Indian Opinion, 2 May 1947.

33. In an interview conducted by the author in Durban on 18 July 2013, Arjun Pillai (a pseudonym), said he was about 15 years old at the time of the royal visit. He graduated from Sastri College, trained at Springfield College and later became a school principal. He worked in the field of education for 40 years. Pillai discussed the disparity in media coverage between the Afrikaans press, as in Die Transvaler, and the English press, saying he believed this had contributed to the rise of Afrikaner nationalism and the National Party success in the 1948 general election.

34. Ramkhelawan Jagkaran, interviewed by the author, Durban, 13 August 2013.

35. Killie Campbell Africana Library: F 968 SOU, booklet entitled "The Royal Visit: South Africa". According to the foreword, the pictures used were taken from various newspapers such as The Cape Times, Rand Daily Mail, The Natal Mercury, and the Sunday Times. 
Most South African newspapers, excluding the Indian press, had souvenir editions printed to commemorate the visit and perpetuate the spectacle of power, imperial loyalty and admiration. ${ }^{36}$

After hearing that the NIC would not be participating in organising an event for Indians to see the royal family, individual organisations inquired with the Reception Committee whether they could participate in other parts of the celebrations. Miss E.F. English asked whether the Indian Women's Association would be given an opportunity to meet with the queen and the two young princesses. Although not directly a member of the association, Miss English included an extensive history of the organisation in her letter and extolled the good it was doing for the general community towards social welfare and education. ${ }^{37}$ Two weeks later she received a reply indicating that the matter was "rather delicate" due to the "attitude" of the NIC. The organisers were apparently having some "difficulty" in making "suitable" arrangements for the Indian community. ${ }^{38}$ As a result, the women were denied the opportunity to view the royal family due to the particular political views of the NIC.

Most working-class Indians (and Africans) were unable to join the royal tour festivities. This was partially attributed to severe racial restrictions, where the South African government hand-selected the people of colour who would meet the royal family. Additionally, many of those who wanted to participate were unable to do so, primarily because of socio-economic reasons. Panjarama Naidoo, who was 15 years old at the time of the visit and living in the regional village of Tugela, recalls that "it was nice, exciting, but we didn't go to see them, because we were busy and can't go. We were at home. We could see it in the papers." 39 Alluding to financial and social obligations that kept her at home, Panjarama Naidoo was forced to "experience" the royal visit indirectly through media representations rather than a much more

36. Recent scholarship has renewed explorations of the divisions and responses to the visit by other South African populations. Hilary Sapire and Albert Grundlingh examine the complicated reactions among white South Africans, especially Afrikaner nationalists. They argue that contrary to the primary goal to "reconcile Afrikaner nationalists and republicans to the imperial tie ... Afrikanerdom was politically fractured and divided in its attitudes towards the monarchical connection". See Sapire and Grundlingh, "Rebuffing Royals", pp 526 and 530; and also Lambert, "Welcome Home", pp 103-104. Analysing African responses to the royal visit, Hilary Sapire argues that the visit signalled the "swansong" of "black loyalism" during the growth of African nationalism in South Africa. Sapire believes that "African engagement with the royal tour indicates that the professed faith in the British monarchy as the embodiment and guardian of the rights and liberties of all peoples living under the British Crown was more widespread and longer lived than is generally assumed." See Sapire, "African Loyalism and its Discontents", p 222.

37. DBN: DBN 4/1/3/1972, E.F. English to A.N. Barker, Honorary Secretary of the Regional Committee, “Re: Indian Women's Association”, 18 September 1946.

38. DBN: DBN 4/1/3/1972, A.N. Barker, Honorary Secretary of the Regional Committee to E.F. English, “Re: Indian Women's Association”, 1 October 1946.

39. Panjarama Naidoo, interviewed by author, Tugela, Natal, 14 January 2015. 
preferred first-hand experience. The key importance of both forms of informal attendance, whether "sneaking a peak" or experiencing it through the newspapers, is that many working-class Indians who could not or were not allowed to attend the Curries Fountain celebration still wanted to be able to experience and celebrate the occasion. Thus, the celebrity pull of the royal family revealed a schism between the "average" Indian South African and the leadership of the NIC at a very critical moment in their history.

Some working-class Indians were confused by the politics of the boycott, questioning why their leadership was willing to send representatives to Great Britain to garner British support but at the same time boycotted the royal family and its highest ambassadors, when they were on South African soil.40 If Indians could advocate for political change in South Africa on British soil, could they not do the same in their own land? Others felt that by boycotting the royal visit, the Indian community was losing a perfect opportunity to positively influence just such international relations that were required to pressure the South African government. ${ }^{41}$

\section{The Pietermaritzburg incident}

The decision whether to support or oppose the boycott on the royal visit was highly contentious among the Indian community of Natal. According to Manilal Gandhi, the editor of the Indian Opinion, the visit was so important "that people who had never taken any part in public affairs, were stirred to do so". ${ }^{42}$ The most tangible evidence of this occurred on 13 February 1947, when a large crowd of several hundred Indians gathered in Pietermaritzburg to pass a resolution condemning the boycott. ${ }^{43}$ However, the meeting turned to pandemonium when representatives from Durban's NIC, notably Dr K. Goonam, Manilal Gandhi, and M.D. Naidoo, arrived with the intention of clarifying the NIC's position on the boycott. S.R. Naidoo, the chairman of the event, refused to let them speak saying that this was a "public meeting confined to Indians of Maritzburg and the District only. [The Pietermaritzburg representatives'] views were to be heard and not the views of outsiders ... nor was the meeting in any mood to hear them." 44 Having gathered with the precise intention of discussing reasons not to join the boycott of the royal visit, these members of the Pietermaritzburg Indian community were frustrated by what they perceived to be a "gang of 'opposition"' participating in a "despicable form of rowdyism", with the sole goal of disrupting the meeting so that the resolution could not be passed. ${ }^{45}$ In fact, Dr Goonam, a well-respected NIC leader and local woman doctor, reportedly "had her

\footnotetext{
40. "The Maritzburg Meeting," Indian Opinion, 21 February 1947.

41. "Welcome to the Royal Family", Indian Opinion, 14 March 1947.

42. "Mr S.R. Naidoo on Maritzburg Meeting", Indian Opinion, 7 March 1947.

43. Pietermaritzburg is the provincial capital, the second largest city, of KwaZulu-Natal. It is located approximately 50 miles northwest of Durban.

44. "Mr. S.R. Naidoo on Maritzburg Meeting”, Indian Opinion, 7 March 1947.

45. “Mr. S.R. Naidoo on Maritzburg Meeting”, Indian Opinion, 7 March 1947.
} 
popularity shattered badly" when disrupting the meeting and was "howled down by the unruly crowd". 46

The fact that a group of Indians organised specifically to pass a resolution condemning the NIC's decision, speaks to the depths of division in the community. The way the leadership reacted to this particular instance of public defiance against their agenda corroded their relationship even further with the Indian masses. Reports of "free fights, scuffles and violent language" throughout the meeting, as well as "police vans [which] stood by all afternoon", illustrates the tension and emotional volatility of the boycott debate among Natal Indians. ${ }^{47}$ In fact, a "Gandhi cap", a once powerful visual symbol of passive resistance, was burnt to ashes in this meeting. ${ }^{48}$ The quite violent struggle in Pietermaritzburg highlights the depth of the disparity between the Indian South African leadership of the NIC and the Indian population at large; between those who understood themselves as Indian nationalists; and those who considered themselves South African nationalists who were involved a freedom struggle versus those who were perfectly content to remain under imperial influence.

On the day of the royal visit to Pietermaritzburg, approximately 10000 Indians were reported as giving the royal family a rousing, "tumultuous" welcome. ${ }^{49}$ About 4000 children were in attendance, escorted by Indian teachers who had volunteered for the event - despite the Natal Indian Teachers' Society's official decision to not participate. ${ }^{50}$ The Natal administrator, Mr Mitchell, presented five prominent people of Indian descent who then given the opportunity to interact briefly with the king and queen, while the Girls' High School performed the Kolathum, a Tamil song of welcome written especially for the occasion. ${ }^{51}$ Despite the vigorous debates in the ranks of the Indian community, the immense and expensive preparations, and the enthusiastic rhetoric of the press, the interaction between the Indian people and royal family lasted less than 30 minutes. ${ }^{52}$ In fact, the royal family were instructed not to leave their car except to mount the dais and receive bouquets. ${ }^{53}$ The local, national, and international press, however, indicated this as a great victory for the British Empire, since the boycott of the visit was "broken down completely" by this relatively brief interaction, with no mention of the brevity of time actually spent with the Indian community. ${ }^{54}$

46. "Split over Royal Visit", The Leader, 22 February 1947.

47. "Split Over Royal Visit", The Leader, 22 February 1947.

48. "Split Over Royal Visit", The Leader, 22 February 1947

49. "Over 10000 Indians Welcome Royal Family”, The Leader, 22 March 1947.

50. "Maritzburg's Participation”, The Leader, 15 March 1947.

51. “Over 10000 Indians Welcome Royal Family”, The Leader, 22 March 1947.

52. PMB: 3/PMB 4/4/2/205, Agenda for the Royal Visit: Pietermaritzburg, 18 March 1947.

53. PMB: 3/PMB 4/4/2/205, Organising Committee to PMB Town Clerk, 5 March 1947.

54. PMB: 3/PMB 4/4/2/205, Telegram, Organising Committee to Pietermaritzburg Town Clerk, 5 March 1947. 


\section{The South African press}

Perhaps the most significant impact on the community was the treatment of the Indian boycott debate in the South African press. The white South African Press (Natal Mercury and Natal Witness) gave sensational reviews of the occasion, painting the Durban NIC representatives as the antagonists who were playing "divide and rule" politics. ${ }^{55}$ The editorial staff of the Indian Opinion, which was led by Manilal Gandhi, gave a lengthy criticism of these newspapers and claimed to provide "the facts". ${ }^{56}$ S.R. Naidoo, the chairman of the event, responded via an editorial in the Indian Opinion, claiming:

... it is not an unusual phase of journalism connected with INDIAN OPINION [sic] to report of public activities in such a manner as to give bad character to those who hold different views from yours. Your paper will persist in giving to the general public half-truths and garbled reports of activities of people who differ from you. ${ }^{57}$

The African press recognised the growing rift that the royal visit had created in the Indian community and the significance of this division on the passive resistance campaign. An article printed two weeks before the monarchs arrived in Durban explained that the visit "provided the Indian moderates with a magnificent opportunity to challenge the Natal Indian Congress" - an opportunity which the moderates readily employed.58 Northern Natal followed Pretoria in organising events for the royal visit, which "spread rapidly" all over Natal, even to Durban, becoming "the fountain and source of inspiration of the passive resistance movement". ${ }^{59}$ Indian merchants often led such celebrations of the British monarchy, and "stated bluntly that they would welcome the Royal family no matter what the Natal Indian Congress said". ${ }^{60}$ Kanvisa, writing for the African newspaper, Inkundla Ya Bantu, went as far as to claim that the "arrival of the royal family will mark the crisis-point for the Indians. By their attitude they will indicate who their true leaders are", and added that "at the time of going to press, the rift was growing wider and wider, with the odds against the present leaders of the Natal Indian Congress". ${ }^{61}$ This was clearly evidenced in the upper echelons of the NIC leadership when Dr Dadoo, president of the Transvaal Indian Congress (TIC) telegraphed Ahmed Ismail, president of the SAIC, explaining that it would be unconstitutional for Ismail to present himself to the royal family on behalf of the Indian community. To which Ismail replied: “... as president of the South

55. "The Maritzburg Meeting", Indian Opinion, 21 February 1947.

56. "The Maritzburg Meeting", Indian Opinion, 21 February 1947.

57. "Mr S.R. Naidoo on Maritzburg Meeting", Indian Opinion, 7 March 1947. Incidentally, Mr S. R. Naidoo was an SAIC representative on the delegation to India in 1946, seeking support from India in fighting the Asiatic Land Tenure and Indian Representation Bill.

58. Kanyisa, “The Indian Passive Resistance”, Inkundla Ya Bantu, 6 March 1947.

59. Kanyisa, "The Indian Passive Resistance”, Inkundla Ya Bantu, 6 March 1947.

60. Kanyisa, “The Indian Passive Resistance”, Inkundla Ya Bantu, 6 March 1947.

61. Kanyisa, “The Indian Passive Resistance”, Inkundla Ya Bantu, 6 March 1947. 
African Indian Congress it was my prerogative and in the best interests of my people to submit myself to Their Majesties". ${ }^{62}$

However, it was the NIC that initially used the media to publicise its views when it sent a letter to the press saying that it refused to participate with the Regional Planning Committee. It was also in the press that the debate raged and where the NIC was publicly castigated. Rather than dealing with the organising committee itself, the NIC chose to make the royal visit a talking point, erroneously thinking that the people would understand their reasoning and be encouraged by their decision. Instead, the backlash from the people was carried out in the press itself, broadcasting the divisions among Indian South Africans to their opponents in the South African government. Emboldened by this, the mayoral secretary responded to the NIC by publishing his own letter claiming that the city was going forward with preparations to provide an opportunity for the Indian community to meet the royals despite the NIC boycott, stating explicitly that since the NIC had released its letter to the Natal Mercury the committee would do likewise. ${ }^{63}$

Furthermore, divisions between the Indian leadership increased confusion amongst their constituency. Ahmed Ismail, president of the South African Indian Congress (SAIC) in a telegram to Dr Y.M. Dadoo, president of the Transvaal Indian Congress (TIC), claimed that the "Royal family's visit has an immediate and widespread response of loyalty from every quarter. My advice to our people is not to mix the politics and grievances into the Royal visit." 64 A statement such as this indicates a disassociation between the political movements of the passive resistance campaign from the perceived loyalty due to the Crown and Commonwealth. This is a vivid indication of the divergence between the "old guard" leadership and the new nationalistic fervour of the "younger" leadership of Dadoo and Naicker. ${ }^{65}$ It highlights the splintered understanding and changing perceptions of Indian identity in postWorld War II South Africa.

Perhaps most significant, was how the British press portrayed the boycott of the royal visit. For example, The Illustrated London News reported that despite a previous announcement of the Natal Indians' intention to boycott the royal tour, many members of Ladysmith's Indian population were "among the welcoming crowds" and Pietermaritzburg Indians "swelled the enthusiastic welcome" which the

62. "Indians and the Royal Visit", Indian Views, 26 February 1947.

63. DBN: DBN 4/1/3/1971, A.N. Barker, Hon Secretary of the Regional Committee to Joint Honorary Secretaries of the Natal Indian Congress, "Re: Royal Visit", 16 September 1946.

64. "Indians and the Royal Visit", Indian Views, 26 February 1947.

65. Similar movements were felt in the African community as well, with growing influence among the African National Congress Youth League (ANCYL) leaders such as Nelson Mandela, Walter Sisulu etc. For further reading, see C. Glaser, The ANC Youth League (Ohio University Press, Athens, 2013); S. Neame, The Congress Movement: The Unfolding of the Congress Alliance, 1912-1961, Vol. 3 (HSRC Press, Cape Town, 2015). 
royals received from the public. ${ }^{66}$ The periodical also listed as one of the three most "notable events of their stay in Durban", the "final collapse of any pretence by the Indian Community of Natal to boycott the Royal Tour, when an estimated 65000 Indians hailed their majesties and the two princesses." 67 Although disregarding the brevity of this meeting and the deep divide it exposed, the international press hailed the breakdown of the boycott as a triumph for the British Empire and for continued white dominance in South Africa.

The division of the Indian South African leadership was mirrored globally among their counterparts in the government of India. Pandit Jawaharlal Nehru counselled the NIC, warning that any boycott of the royal visit was inadvisable and that overt demonstrations should be avoided at all costs. However, the NIC failed to share this information with the public promptly and those opposing the NIC view made prime use of this failure to validate their cause. ${ }^{68}$ Instead, the NIC clung to the weight of Gandhi's support for their cause. On several occasions, the Indian Opinion, the mouthpiece of the NIC, reminded its readership that the Mahatma believed the NIC was correct in its belief that boycotting the royal visit was appropriate when living under such a discriminatory government. Endorsing the "abstention as national and dignified", Gandhi went further, claiming that the royal tour was the "rejoicing of white people" despite the "disabilities imposed upon Asiatics, Africans and other Coloured peoples" and that in this light a boycott of the tour events was fully justified. 69

The significance of Gandhi's support, and the NIC's use of it, is evidence of the influence and weight of the personage of Gandhi. Those who were willing to go against the wishes of their own political leadership back in India were reluctant to second-guess Gandhi's directives. As a result, the NIC downplayed Nehru's dissent and repeatedly reminded its constituency of Gandhi's support of the boycott, hoping to prevail on this sentiment when all others might fail. Even the extremely high regard so many held for Gandhi was not enough to prevent most Indians from celebrating the arrival of the royal family, which is perhaps the starkest example of the divide between the people and the NIC leadership. Whether political or not, a large percentage of the Indian South African masses wanted to participate in the visit in some fashion. Thus the fact that the NIC did not understand that many Indian South Africans simply wanted to be a part of a momentous historical event, demonstrated how out of touch they were with the sentiments of the people.

66. Illustrated London News, 5 April 1947.

67. Illustrated London News, 5 April 1947.

68. "The Royal Visit", Indian Opinion, 28 February 1947; "Indians and the Royal Visit", Indian Views, 26 February 1947.

69. "Mr Gandhi Endorses Boycott of Royal Tour", The Leader, 8 March 1947; and "Indians and the Royal Visit", Indian Opinion, 31 January 1947. 


\section{Conclusion}

In early October 1947, the NIC held a mass rally to mark the opening session of the United Nations. Several groups of resisters courted arrest. The mass rally, according to C.M. Anglia, a Working Committee member of the NIO, was only attended by 1500 people, as compared to the 7000 and 10000 who attend similar mass rallies in 1946 . Anglia believes it was "significant that 2,000 Hindus attended [a NIO] meeting at Albert Park, [Durban]", while also claiming that many at the NIC meeting attended out of "curiosity" which demonstrated the NIC's loss of support from within the Indian community. ${ }^{70}$ As a result of the royal visit, A.I. Kajee felt he had a mandate to speak for the Indian community. He established the Natal Indian Organisation (NIO) on 4 May 1947, a mere six weeks after the royal visit, and was then selected by Smuts to attend a "goodwill mission" to Pakistan later that same year. Kajee's willingness to work with Smuts in negotiating Indian interests marked him as a "collaborator" in much of the Indian press. Perhaps more importantly, however, he provided the white government the foil it needed to succeed in convincing the UN that most Indians in South Africa were actually quite content with the state of affairs. In so doing, Kajee created the impression that those who advocated passive resistance were a disconnected minority.

Whether formally invited or by 'sneaking a peek' at the festivities, Indians turned out in their thousands to see the British royalty. These were numbers unheard of in the passive resistance campaign which saw 2000 activists being arrested over the course of its two-year campaign. ${ }^{71}$ Such strong disregard of the boycott made it obvious to all that the Indian political leadership (notably the NIC) was not as strong and influential as it claimed and that the wishes of the people and the directives of the leadership were at odds. The South African government took full advantage of this apparent rupture. Heaton Nicholls, the Union's high commissioner told the press on 24 April 1947, that it was now very obvious that the vast majority of Indians in the Union were opposed to the action taken by India in the UN. This, he claimed, was patently clear in the refusal of the Indian community to obey the NIC in its boycott of the demonstrations to welcome the royal family. They saw themselves as South African nationals and resented the idea of being "dragged into the Indian political arena". ${ }^{72}$

70. “Thirty-Nine Resisters Go to Gaol”, Indian Opinion, 17 October 1947. Anglia also cites Dr Naicker's admission that NIC delegates were attempting to raise funds in East Africa as proof that the "local Indians, who subscribed between $£ 30000$ and $£ 40000$ last year have now withdrawn their support."

71. "Passive Resistance Suspended," Indian Opinion, 11 June 1948; A. **Desai, "The 19461948 Passive Resistance Campaign in Natal, South Africa: Origins and Results," Journal of Natal and Zulu History, 31(2018), pp 54-67.

72. "What Mr. Heaton Nicholls Tells the World," Indian Opinion, 2 May 1947. 
The NIC attempted some damage control, claiming that there were "various reasons", why South African Indians wanted to celebrate the royal visit, such as fear of losing their jobs as a result of white reprisals, and that none of this meant there had been a significant shift in general attitude towards the racial policy of the government. ${ }^{73}$ Nevertheless, such reports found their way to the UN General Assembly in 1947, where this "comparatively unimportant event" played a significant role in discrediting statements made by the Indian South African leadership at the UN, because its role as speakers for their community was questioned. ${ }^{74}$ The royal visit highlights the gap between the Indian leadership in South Africa and many other local Indians, not just in political views, but also in how they identified themselves within the Indian community, the nation, and the British Empire. Because it made the rupture so obvious, the South African government capitalised on this at the UN. What many remember as a very non-political event had significant and long-range political implications.

\section{REFERENCES}

Aronson, T., Royal Ambassadors: British Royalties in Southern Africa 1860-1947 (David Philip, Cape Town, 1975).

Arnold, D., Gandhi (Longman, New York, 2001).

Bhana, S., Gandhi's Legacy: The Natal Indian Congress, 1894-1994 (University of Natal Press, Pietermaritzburg, 1997).

Brown, J., Gandhi: Prisoner of Hope (Yale University Press, New Haven, 1998).

Calpin, G.H., A.I. Kajee: His Work for the South-African Indian Community (Iqbal Study Group, Durban, c. 1950).

Desai A. and Vahed, G., The South African Gandhi: Stretcher-Bearer of Empire (Stanford University Press, California, 2016).

Desai A. and Vahed, G., Inside Indian Indenture: A South African Story, 1860-1914 (HSRC Press, Cape Town, 2010).

Desai, A. and Vahed, G., "Monty... Meets Gandhi ... Meets Mandela: The Dilemma of Non-Violent Resisters in South Africa, 1940-60", in Hofmeyr, I. and Williams, M. (eds), South Africa and India: Shaping the Global South (Wits University Press, Johannesburg, 2011).

Desai, A., "The 1946-1948 Passive Resistance Campaign in Natal, South Africa: Origins and Results", Journal of Natal and Zulu History, 31(2018).

Dhupelia-Mestrie, U. and Bhana, S., "Passive Resistance among Indian South Africans: A Historiographical Survey", South African Historical Journal, 16(1984).

Dhupelia-Mestrie, U., "Indian Responses in Natal to Non-European Unity Moves, 1927 to 1945 ", Journal of Natal and Zulu History 12 (1989).

Dibben, M., "The Royal Tour of 1947", Honours essay, University of Natal-Durban, 1985.

73. "What Mr. Heaton Nicholls Tells the World," Indian Opinion, 2 May 1947.

74. *Barr, "A European View of the Boycott of the Royal Visit," Indian Opinion, 14 March 1947. 
Dubow, S., "Smuts, the United Nations, and the Rhetoric of Race and Rights", Journal of Contemporary History, 43(2008).

Glaser, C., The ANC Youth League (Ohio University Press, Athens, 2013).

Guest, B., "Gandhi's Natal: The State of the Colony in 1893", Natalia, 23 (1993).

Hiralal, K., "Indian Family Businesses in Natal, 1870-1950”, Natalia, 38 (2008).

Hofmeyr, I., Gandhi's Printing Press: Experiments in Slow Reading (Harvard University Press, Cambridge, 2013).

Huttenback, R., Gandhi in South Africa: British Imperialism and the Indian Question, 1860-1914 (Cornell University Press, Ithaca, 1971).

Lambert, J., "'Welcome Home': White English-speaking South Africans and the Royal Visit of 1947", South African Historical Journal, 69 (2017).

Lelyveld, J., Great Soul: Mahatma Gandhi and his Struggle with India (Alfred Knopf/Random House, New York, 2011).

Neame, S., The Congress Movement: The Unfolding of the Congress Alliance 1912-1961, Vol. 3 (HSRC Press, Cape Town, 2015).

Pachai, B., The International Aspects of the South African Indian Question, 1860-1971 (C. Struik, Cape Town, 1971).

Reddy, E.S., Struggle for Freedom in Southern Africa: Its International Significance (Mainstream, New Delhi, 1987).

Sapire, H., "The 1947 Royal Tour in Smuts' Raj: South African Indian Responses”, in Aldrich, R. and McCreery, C. (eds), Royals on Tour. Politics, Pageantry and Colonialism (Manchester University Press, Manchester, 2018).

Sapire H. and Grundlingh, A., "Rebuffing Royals? Afrikaners and the Royal Visit to South Africa in 1947", The Journal of Imperial and Commonwealth History 46 (2018).

Sapire, H., "African Loyalism and its Discontents: The Royal Tour of South Africa, 1947", The South African Historical Journal, 54 (2011).

Sapire, H., "Ambiguities of Loyalism: The Prince of Wales in India and Africa, 1921/2 and 1925", History Workshop Journal, 73 (2012).

Shearar, J., Against the World: South Africa and Human Rights at the United Nations 1945-1961 (Unisa Press, Pretoria, 2011).

Soske, J., Internal Frontiers: African Nationalism and the Indian Diaspora (Ohio University Press, 2017).

Swan, M., Gandhi: The South African Experience (Ravan Press, Johannesburg, 1985).

Thompson, A., "The Languages of Loyalism in Southern Africa, c. 1870-1939", The English Historical Review, 477(2003).

Vahed G. and Waetjen, T., "Shifting Grounds: A.I. Kajee and the Political Quandary of 'Moderates' in the Search for an Islamic School Site in Durban, 1943-1948", South African Historical journal, 67(2015).

Vahed, G., "The Making of Indian Identity in Durban, 1914-1949”, PhD thesis, Indiana University, 1995.

Viranna, B.L., "Black Political Resistance in Natal, 1947-1952", Master's dissertation, University of Durban-Westville, 1994.

Welsh, D., The Rise and Fall of Apartheid (Charlottesville: University of Virginia Press, 2009). 
Hoyer - Indian South Africans and the 1947 royal visit

Witz, L., Apartheid's Festival: Contesting South Africa's National Pasts (Bloomington: Indiana University Press, 2003). 